\title{
Rachel Weiss AND THE CHANGING FORTUNES OF UTOPIA IN THE NEW CUBAN ART
}

In a neat schematic for what he calls 'the prison house of meaning,' David Joselit has mapped the various locations of where art does what it does. Works in which the meaning resides 'beside' the work correspond to a social vocation. When the import or impact is found 'behind' the work then we're in the presence of iconography. And when meaning lies in the future, he says, then we're dealing with art as utopia. ${ }^{1}$

Utopia is always a contentious subject, and perhaps never more so than in cases where it has been taken seriously by people who are still alive. Cases,

${ }^{1}$ Joselit, D. (2007, February). Remarks delivered at CAA conference. 
that is, like Cuba. I'll confess that the theme of utopianism is one that I'm reluctant to emphasize too much in relation to Cuban art, since utopia is so often understood in terms of idealist dreaming and the key thing about recent art in Cuba, in my view, has been its very real agency and social presence, in its own moment. Nonetheless, many of the artists have been propelled by what we'd have to call a utopian impulse, namely the idea that art could actively participate in the process of building a just society. And their utopian faith in art was, of course, in continual dialogue with the utopian project of the Cuban Revolution overall, even if it was increasingly at odds with it.

The pattern I'll trace here is of something that has come to be called the new Cuban art. It's an art that, in the course of a few rapid-cycling iterations, was nested within, and in some sense tried to cope with the utopian project of the Cuban revolution and which then, after less than a decade, already had to contend with its own utopian legacy and with the double exits of exhaustion and exile. An unreliable corpse, however, the new Cuban art then reconstituted and rededicated itself, in apparently parallel though very different terms. All of this, by the way, between around 1981 and 2001.

It's a story about art moving to and from utopia, in which the inverse journey is no less fuelled, and no less prefigured, by the energies and commitments of utopian ideas. This is a history in which the figure of return is a primary architecture, and at various points that doubling has signaled everything from reassertion to refutation. As this suggests, a major element I'm interested in here is that of generational transfer, of how the utopian cargo-whether felt as legacy or burden - moves from one generation to the next (and keeping in mind that in Cuba an artistic generation only takes about 5 years). 
Utopia in this art had to do with constituting or repairing a social body. As an arena, it was not only fundamentally social but also quotidian — a space very close at hand, not the utopia of the horizon. In place of utopian certaintieshowever prospective and future-oriented-, it formed a landscape of negotiation, as befits the condition of daily life. A dream not so much of destiny, but of belonging. Precisely because of its social basis it was an argumentative rather than narrative kind of utopian voice.

The first few years of this "Cuban Renaissance" had a strong spirit of recuperation and renewal, with a lot of the work emerging from an anthropological or a vernacular grounding. Idioms ranged from Afro Cuban spiritual traditions to kitsch (in both popular cultural and ideological forms) to an extremely personal and de-heroized adoption of revolutionary mythology. The work occupied an everyday space, keeping in mind that the everyday was, of course, the site of Cuban socialism's most important promises: housing, health care, education and dignity. Artists created a novel everyday, whose range intersected the political, ethical and ideological; a social field that lived in a permanent quarrel with the theological and metaphysical; an actual, which worked to correct the speculative's bad memory. Most of all, this everyday was a space of interaction, the place where meanings were built through social relations and where the social body came into being.

Cuba, as a socialist society, obviously accepted the idea of a collective body as its very substance: the social body in toto is claimed to be, or at least aspired to be, a collective. But what interests me here is the compound body that has been created in various ways over the decades as Cuban society 
formed and re-formed a whole cascade of bodies - collectives-within-the collective, we might say. To form a collective-within-a-collective somehow confounds the overall project since it demarcates zones of separateness, and in fact an absolutely crucial aspect of artistic activity from around 1986 until the mid-90s was the work of small and mostly informal collectives. This might sound paradoxical, but it's through these collective projects that I want to take up the question of utopian energy in the new Cuban art.

By the second half of the 1980s, a significant shift in artistic production had begun to take place. This was spurred both by the fact of generational transfer and a rapidly changing national political and economic landscape (the result, in part, of perestroika and glasnost in the USSR). As the Cuban situation deteriorated into a crisis of intense ideological isolation and the beginnings of profound economic collapse, the work of younger artists took on an urgency and radicality that matched those new circumstances. Many of the artistic proposals of those years sought to reinscribe a space for a critical culture within the broad emergencies that were quickening at the time. It was an astonishing interval in which young artists wound up leading the way in raising for public discussion the taboo subjects of corruption, dogmatism, cult of personality, lack of democracy and so on.

Art was in the middle of things. It was an acceleration of force, a performative extension concerned with public space in the form of a collective being or will. The audaciousness of the young artists soon rose up into a sustained, raucous crescendo, as did the velocity of their public presence in Havana, as did the battery of retaliations against them. The new Cuban art became an uproar. 
In some cases the works took up residence in and took issue with 'art' — and in others they rejected that cloister in favor of 'public' space - though it may be worth it for us to rethink this question of what really counts as 'artistic' and/or 'extra-artistic.'

Among the former were works such as Arte Calle's No queremos intoxicarnos, an intervention at a roundtable discussion on "The Concept of Art" to which they arrived wearing gas masks and carrying placards mocking political slogans: "Art critics: know that we have absolutely no fear of you," (mimicking the billboard which has stood for years in front of the US Interests Section, declaiming "Señores imperialistas, know that we have absolutely no fear of you!").

Significantly, though, Arte Calle also painted murals on the run, fulfilling their promise of taking up positions in the city, whether in obscure corners or right in the middle of things. What's significant about these projects are the kinds of energies they created and released in public space. In one of their earliest outings, before the day was out, the neighbors had taken over what had started out as basically a neighborhood beautification project and turned it into a full-on public carnival, even calling in fire fighters to participate so they could climb their ladders and shoot their water hoses, all as part of making a nice painting on a building wall.

Arte Calle's nocturnal guerrilla actions fed avid rumor circuits throughout Havana, elasticizing the institutional borders of art. When they made a mural that said "Art is just a few steps from the cemetery" in front of the Colón Cemetery in Havana, a rumor spread that a group of youngsters had painted 
a poster on a tomb that said "Freedom has been buried by the Revolution." Or, when they abbreviated the group name in signing a mural as "AC," people would interpret it as "Abajo Castro" ("Down with Castro").

Grupo Provisional started at more or less the same time as Arte Calle, and shared their anarchic ethic, their roughhouse aesthetic tied to the punk and rockero subcultures and, most importantly, their para-artistic conception of art's relation to politics.

Grupo Provisional's 1988 performance "Very Good Rauschenberg" took place on the occasion of Robert Rauschenberg's gargantuan ROCI-Cuba (Rauschenberg Overseas Cultural Exchange-Cuba) exhibition that was stuffed into Havana's museums and galleries at the time. Provisional stormed the National Museum's auditorium bearing signs reading "Very Good Rauschenberg" which they insisted (in Spanish, which he did not understand) that the befuddled artist autograph. Meanwhile Aldito Menéndez, dressed only in a loincloth and sitting on the floor directly before the artist, listened intently and inscrutably. Provisional's silly, faux-groupie play farted on myth at several levels, from the art student's adulation of fame, to the antiimperialist position of the Cuban national institution, the 'Indian's' warm embrace of the conqueror, and the 'universality' of the language of art.

But it was not all a joke. Arte Calle staged "Easy Shopping" in 1988 as a response to the government's establishment of casas de oro, establishments that bought back gold and silver heirlooms from citizens in an attempt to generate hard currency revenues. In the artists' view this amounted to the return of Hernán Cortés: "the Spaniards come with their little mirrors, the 
Indians hand over the gold," as they later put it. ${ }^{2}$ As a gesture of anti-neocolonialism they painted their bodies gold and silver and paraded through the Old City's streets until, having attracted a substantial crowd that followed them to the edge of the harbor, they threw themselves into the filthy, oilslicked waters. It was, according to Glexis Novoa, "like an act of suicide. For ethics". ${ }^{3}$

Performances, exhibitions, interventions, debates, disturbances, aggressions, retaliations and counter-retaliations all piled up like tightly packed isobars throughout 1987, '88 and '89. The wave carried a feeling of danger, an affirmative aggression as popular as it was energetic-popular precisely because it pulled the rug out from under the hero worship and piety of officially mandated selfhood, and replaced it with an imbedded pest. The work was charismatic not only for its humor but also for what it did to public space: the rising pulse of activity created a sense of public dialogue, accumulating into a substantial and ongoing presence. Gossip and rumorhistorically among the most important means of communication on the island - spread the word about the constant onslaught of events, attracting a public that was not only effervescent but also heterogenous. Never before had stories about visual art "been on the lips of workers like one incendiary more," as Aldito Menéndez put it. ${ }^{4}$

Meanwhile, the group Art-De (Arte-Derechos) staged a series of weekly events in a popular city park, taking the decisive step of abandoning 'art,' and

2 Novoa, G. (n.d.), personal communication.

${ }^{3}$ Ibid.

${ }^{4}$ Menéndez, A. (1988). La revolución del arte y no el arte de la revolución. Havanna: Typescript. 
the shelter of its various institutional mechanisms. The Brigada Hermanos Saiz (the youth wing of UNEAC, the Cuban Artists' and Writers' Union and therefore an organ of the Communist Party) had actually provided support and cover for even the most provocative works - so long as they were legitimated on the grounds of being art. The Brigada's role was to manage the situation, working with the manifestations of the "adolescent rebellion" to produce a more positive dynamic. But Art-De's cardinal sin was to position itself outside of this official safety net, seeking neither recognition as art nor the support of the cultural apparatus for the presentation of their work. By taking over public space and inviting totally unmediated participation from anyone, there was, as one spectator put it, "no divorce between their role as citizens and as artists." Me han jodido el ánimo (They've Fucked Up My Spirit) was a typical work for them: in it, Juan-Sí González wrapped himself in a large plastic bag and slowly suffocated in a display of existential agony until a panicked spectator finally stepped in and tore the plastic away from his face. The happenings in the park magnetized crowds, and became the site of extraordinary public debates about Cuban society and its problems.

With their direct invocation of the issue of human rights, Art-De brought into play one of the dilemmas that artistic collectives faced under socialism: in Cuba, where priority is placed on a collective conception of human rights, Art-De located those rights within the individual, as is typical in western liberal tradition. By forming a collective based explicitly in political dissentand it's worth emphasizing that they were the only one of the artist collectives that positioned itself as dissident - they declared the socialist collective

\footnotetext{
${ }^{5}$ At first these events were held in the Coppelia park in Vedado every Wednesday afternoon for four weeks: permission to use the site was then withdrawn, and the group moved to a park at the corner of $23^{\text {rd }}$ and G, also in Vedado. The group was then prohibited from working further in public.
} 
promulgated and prophesized by the state to be a fraud. And of all the contestatory groups, it was Art-De that received the full measure of the State's displeasure.

While there may have been general agreement among artists about goals, there were real differences on strategy and tactics. These were perhaps most clearly manifested in the piece done by an assembly of artists in the Plaza de la Revolución on the occasion of Che Guevara's $60^{\text {th }}$ birthday in 1988 , twenty years after the martyr's death. The Youth Ministry solicited the young artists to do a work for the occasion, as part of a policy of constructive engagement with Cuban youth who were agitating for change.

After much debate, the group decided to make a large sign reading MEDITAR, a plaintive demand for reflection. The other option that had been considered was a much harsher statement, restaging an earlier work by Aldito Menéndez that consisted of a sign reading Reviva la revolu...-- mocking the revolutionary slogan and meanwhile suggesting that the revolution was not only unfinished but a mess. The disagreement among the artists was not only over the conciliatory tone of the MEDITAR idea, which was a basically reformist proposition, but also with regard to the nature of the pact with power that would, or would not, be conserved. The way that some artists formulated things at the time, the goal was not the overthrow of socialism but rather the emergence of a 'real,' or 'radical' form of it. In these terms, the neutral, philosophical and inoffensive tone of MEDITAR represented a fundamentally unacceptable compromise in agreeing to coexist with power, and on terms acceptable to it.

On Sept. 24, 1989, practically every artist and critic left in Havana met up in the old Vedado Tennis Club in Havana. The event had been announced on a 
few posters around the city under the banner of "Cuban art dedicates itself to baseball" and, forewarned, State Security had arranged a game of its own on the next field over. "If we can't make art, we'll play ball" the artists said and that's exactly what they did, on the day that many consider to have been the swan song for the new Cuban art.

It has often been said that what the young artists accomplished was to "say out loud what everyone was thinking," but it was probably more than that: the dynamic exchanges they set in motion changed the nature of discussion about the country's problems, and thrust it into public space. The avalanche of events and performances in Havana was almost entirely organized by the artists themselves, and so it was a kind of public address that left behind the designated physical spaces of art and its institutional horizon, framing the artistic context rather than being framed by it.

Official reaction to the artists was increasingly harsh. By 1989 exhibitions were being closed almost routinely, apparently under the direct supervision of the ideology chief of the Cuban Communist Party, because of content that was deemed to be offensive, counter-revolutionary or irredeemably ambiguous. Although no new policy was announced, it became possible for artists to emigrate. This was either an effort to rid the island of the pest or to get the artists out of harm's way, depending on who you ask, but in any case the artists' facilitated departure was sharply contrasted by the horrific spectacle of thousands of others who left - many of whom died- on improvised rafts in the same years.

On the island, the 1990s began with the near-total collapse of the nation's viability, both economic and psychic-including precipitous drops in the 
availability of food and basic goods, transportation and electricity, not to mention hope. There was a concurrent spike in rhetoric and the public performance of commitment, and a concurrent (triangulated) ascendance of the doble moral, the new gold standard that underwrote the new dollarized economy. The everyday was now (again) stealing, lying, pimping, hustling, deceiving, disbelieving, desperation, cheating, embarrassment, shame: survival. Artists then coming of age had to contend not only with the orphaned status that resulted from the exodus, but also with a daily struggle for survival and a generalized disillusionment that was as pervasive as it was profound.

The exodus and Special Period were blows against the body of collectivism and solidarity. Tania Bruguera felt the loss with particular force, and her 1993 project Memoria de la postguerra had the utopian ambition of bringing the dispersed, broken body of the new Cuban art back into a totality-not only among those in Havana but rejoining them with those who had left, no matter how provisional and fragile that reunion might be. With Memoria, it became clear that the collective was as much a figure of mourning as of generation. With Memoria, the idea of mourning as a constituent element of utopia was introduced.

Strategically and sarcastically, Bruguera produced Memoria de la postguerra as an underground newspaper that collected work from across the diaspora, and its unpublishable compendium concluded with a list of 106 artists who had recently left. Memoria embodied the camaraderie- protective, jumpy, benighted, and blasphemous as ever- of the new, chastened present. But for all of Bruguera's mournful tone, the paper was marked by a very strange mixture of torment and silliness. With its ambiguous logo (the lettering either the work of a rushed street graffitist or else a victim's last words, dripping in 
blood) and mock promotional campaigns (that included matching plastic ashtrays), Memoria was a difficult work to parse.

The war was over and Memoria was at the press conference, held at "the Center for the Salvation of Plastic Arts, in the capital." A painter confirmed the rumors, Rafael López Ramos reported, "although an armistice has not been signed." "Asked by this reporter about the possibility of a rejoining of forces by the army known in bygone days as Young Art, he responded with a laconic "No comment". 6

When grand programs have failed, the space around the edges gains enhanced authenticity. In the early 1990s, the rhetoric of community supplanted that of the collective - a more intimate and unrehearsed formulation. It was a romantic turn.

Romanticism's ethos of the personal repudiated social consensus, and injected doubt into the heart of ideas about history and destiny. If, as Adorno had it, the loss of utopia is the loss of the capacity to "imagine the totality" as something radically different, then this occasioned, in the new Cuban art, a rethinking of the most basic question of socialism, namely of the individual's identity vis-à-vis the collective. And so it was not just the limits of tolerance that changed, but the very persona of the individual as agent in society.

Much art is motivated by conflict, and the question of the relation between private and public had been also a question about where the conflict was seen

${ }^{6}$ López Ramos, R. (1993). Special assignment to Memoria de la postguerra, "La Guerra ha terminado afirma joven artista cubana". Memoria de la postguerra, 1 (1), p. 5. 
to arise. For many artists, the deep internal corrosions of life in the Special Period had located the most urgent conflicts within themselves. While the public space that was imagined before was a valiant one where important things were possible, once faith in that possibility died, the revolutionary Public repaired to the domestic, distaff space, or to a public space that was now relatively minor.

A new bunch of collectives formed in these shadows. It was not only nostalgia, though it was certainly that in part: an almost schizophrenic sense of vocation took hold, at once a suspicion verging on conviction that art's radical calling had become anachronistic, and a powerful desire for exactly that kind of restorative, self-determining agency. But the young students were not simply pawns or surrogates; they were youngsters - again - unrequited in their idealism and yearning to be artists in a way that mattered: mattered deeply, mattered broadly, mattered as Cuban. René Francisco's DUPP (Desde una pedagogía pragmática, From a Pragmatic Pedagogy) was the first of these new collectives to solidify, and the new era was marked by René's own rebirth in Beuysian vest and fedora.

Art-into-life returned, or remained, as a dream, but now as a means of escape from the orbit of the official, the administered, the deadened falseness of consensus and collectivity. The new collectivity entrusted the responsibilities for proper conduct of the society to the private sector, and to the even smaller subset of the individual: a kind of Dickensian belief that it was in the cultivation of empathy for the sufferings of others that social change could be effected. It was a politics of compassion and description, definitively not mass, and definitively not confrontational. 
La casa nacional was DUPP's first project, done in 1990, and it consisted of making home improvements in a solar. The artists solicited the inhabitants of the slum and fulfilled their requests - which included, for example, "repairing personal objects, remodeling the house, paint for doors, numbers to identify its rooms, dining tables, pictures of martyrs for the communal living room, pictures with religious themes and with descriptions of historical characters, a mural to give information about the community, a plaque to identify the building historically, cleaning the house and update chats with the neighbors". 7

"Projects of social-cultural insertion" had been a mainstay of the early 1980s in Cuba, and had been undertaken from both sides of the artist-institution fence. One collective project in particular, undertaken the year before in the remote and impoverished town of Pilón, was a key antecedent for DUPP's ministrations. The project in Pilón was utopian, and some read it as utopianrevolutionary. The artists' idea was to live together with the people of Pilón, and to make art with them in a fully collaborative process. The work, and the idea of "art," would arise from those people and that place, not from any prior expertise or professionalism that the artists brought with them.

The project's move out of the gallery and museum - like Arte Calle's street commotions or Art-De's actions in the parks - drew a parallel between the idea of the public body and public space, and implied a change in the identity of the spectator that was being sought. But it went further: the project was

\footnotetext{
${ }^{7}$ Francisco Rodríguez, R. (1990). La casa nacional.
} 
structured such that - in removing all of the assumptions and tacit agreements about art- it fundamentally challenged the artists' view of themselves and of what they were doing. In this, it was perhaps the most honest collective project of all, if we understand collectivity as essentially a manner of relinquishing the defended self-identification in search of a truly social one.

Against that historical backdrop, DUPP's revival of "projects of social insertion" in the 1990s took on an ambiguous status. The old avant-garde dream of art-into-life again raised its head, but then mostly settled for a conflation, or confusion of the two, an aestheticizing remediation of the everyday.

With the ideational core of collectivity hollowed out, the impulse to come together came mostly from a need to "belong to something." With that spirit infusing both its utopian rhetoric and the lyrical dystopianism of its intervention, La casa nacional was, in many ways, a moment of willed innocence, a wistful gesture made in the face of the enormous new fear of the future that gaped across the country. And although it is easy-too easy, probably - to dismiss the project as opportunistic, or light, that would keep us from noticing something important: the assumed substrate of promise. But it was a different kind of promise, neither of the horizon nor the abyss, but one of lateness.

Lateness was not simply a function of age, maturity, failure, or some combination thereof, and its relation to loss was not simple or direct. It was lateness in the sense that the dying Edward Said used the term, as a 
"catastrophic commentator on the present" ${ }^{8}$ It had to do with creativity after the engines and inspirations of youthful hope had to be left behind by young people. La casa nacional's lateness had nothing to do with snatching victory from defeat; in fact it had nothing to do with victory (although it would have been impossible without defeat at some point).

This lateness might indeed have been a transitional time and state but, if it was, that could never be evident because La casa nacional's lateness did not place its bets on what it paved the way toward: it therefore had to simply fill itself with what it was, along with what little it could rescue from the past without undue keening. This is the prerogative of late style: "it has the power to render disenchantment and pleasure, without resolving the contradiction between them." Ultimately, according to Said, lateness comes when the limits of art have been encountered, but it does not satisfy itself with accepting them. Late works are the catastrophes, "able neither to draw back from nor fully to consummate [the] desire for the beloved, yet elusive object". 9

The reiterated desire to fuse art and life in DUPP's works, among other things, was strangely also a means of depoliticizing, or apoliticizing, it. The "life" that received attention was "daily" rather than "ideological," as though those realms could be so surgically detached from each other. A minimization of the maximalist proposition of the earlier, more utopian proposition regarding art, DUPP's iteration of the old dualism often sequestered "life" in the smaller

\footnotetext{
8 Said, E. W., Said, M. C., Wood, M., \& Said, P. E. W. (2007). On late style: Music and literature against the grain. New York: Knopf Doubleday Publishing Group, p.14.

${ }^{9}$ Ibid., p. 160.
} 
zone of privacy, an ideology that renounced "ideology" and mustered its own, sad, tautological demise. DUPP had discovered a terrible quandary.

Just slightly later on, Lázaro Saavedra's students banded together as the collective Enema in mid-2000. The group's name — which means the same in Spanish and English — was a succinct declaration of their opinion of Cuban art, what it had become, and what it needed. Living in and working out of the national art school's derelict facilities, the students developed an artistic practice that consisted in using classic performances as readymades, and reenacting them. They were especially drawn to the kind of harrowing, somatic works that artists like Marina Abramovic and Chris Burden produced in the 1960s and 1970s, based in physical ordeals, tests of endurance and quietistic displays of pain.

The collective body itself was Enema's principal concern, and their performances often manifested it as the site of difficulty, conflict, or impossibility, with a recurrent motif of individual bodies forced into a kind of trans-individuality that never quite fuses into a collective self. The overall effect was of an ambivalent, estranging zone in which the continual passage back and forth between individual-and-collective manifested an enormous tension between public and private selves, between confession and display. This was never more forceful than in Uds. ven lo que sienten/Nosotros vemos, their reprise of Abramovic's 1984 You See What You Feel I See, which they knew about from a single black-and-white photograph. Enema took the original work's odd, occult feel into public space, hanging by their ankles for 25 minutes, hands behind their backs, from scaffolding erected in the middle of a gallery patio during the opening of the National Salon. The artists dangled silently, high above the crowd, their presence and perception inverted from 
it, and meanwhile a live video feed doubled the inversion: the crowd saw them upright in the monitors but bizarre, hair pulled vertically, expressions strained by an invisible reverse gravity. A shocking, incomprehensible, mesmerizing private space, thick around these spectral cocoons, overflowed the gaiety of the event and silenced it.

Although Enema was often seen as a revival of the "spirit of the ' 80 s," they had a relationship to the cultural apparatus that complicated that continuity: their projects were facilitated and funded by the state. Thus, although for example in April 2001 they restaged the infamous Baseball Game, theirs was done with the cooperation - rather than in defiance of - official agencies. "It was like Ah Ha!," one member explained, "like an action of the '80s but in the spirit of the '90s. It was like, The artist has acted — the artist of the '90sand has survived and has gotten involved and has understood how it works." The collective had become a supple enough vessel to contain various contradictions: both outlaw and client, refuge and launchpad.

However uncompleted it may be, what's striking about this history is its persistence, its continual return to some version of the utopian formulation in spite of repeated failure and disappointment. It has been through artist collectives that some of the most important work was done-important in the sense of being meaningful participants in a process of transformation, of social betterment - and it was also in self-defining as a collective, rather than simply as part of the assumed mass collective of the socialist public body, that these artists most clearly articulated their own agency in relation to the utopian dream of revolution. The operative sense of utopia here-if we can use that term - is of an art that has clear and unique agency, that is capable of acting on and in history - in other words, a utopia of creativity. This is a 
utopia that has to do with three main factors of special interest to me, namely of a utopian formulation that revolves around creative activity, a utopian process rather than utopian plan or object and finally of a significant interplay between that creative output and people and questions that extend well beyond the usual reach of 'art', that has a magnetizing and catalyzing effect on public space.

"The finished time of tragedy," Marc Augé wrote, making a case for oblivion, and the "continuing time of the return". ${ }^{10}$ That 'return' is the key. What I've tried to do here is trace a dynamic of striving that passes from one moment to subsequent ones, from one generation to the next. A dynamic that was continually reformulating itself in order to do new work, despite all the news to the contrary. Whether refried, 'late,' or otherwise tarnished, utopianism has been-I would argue - the key energy that kept Cuban art intent on an ambition of social justice. The asymptotic nature of this trajectory-probably inevitable, and the result both of the difficulty of achieving such a goal and also of the very nature of art - is a propellant as much as it has been a marker of failure. I wouldn't discount the importance of either factor in trying to understand this lingering impulse, and this insistent itch, toward utopia.

10 Augé, M., De Jager, M. (trans.). Foreword, J. Y. E., Auge, M., de Jager, M., \& Young, J. E. (2004). Oblivion. Minneapolis, MN: University of Minnesota Press, p. 67. 


\section{References}

Augé, M. (2004). De Jager, M. (trans.). Foreword, J. Y. E. Auge, M., de Jager, M., \& Young, J. E. (2004). Oblivion. Minneapolis, MN: University of Minnesota Press.

Francisco Rodríguez, R. (1990). La casa nacional.

Joselit, D. (2007, February). Remarks delivered at CAA conference.

López Ramos, R. (1993). Special assignment to Memoria de la postguerra, "La Guerra ha terminado afirma joven artista cubana". Memoria de la postguerra, 1 (1).

Menéndez, Aldito (1988), La revolución del arte y no el arte de la revolución. Havanna: Typescript.

Novoa, G. (n.d.), personal communication.

Said, E. W., Said, M. C., Wood, M., \& Said, P. E. W. (2007). On late style: Music and literature against the grain. New York: Knopf Doubleday Publishing Group. 